\title{
LEAD ISOTOPIC COMPOSITION OF THE OLDEST VOLCANIC ROCKS OF THE EASTERN GREATER ANTILLES ISLAND ARC
}

\author{
G.L. CUMMING and S.E. KESLER \\ Department of Physics, University of Alberta, Edmonton, Alta. T6G 2J1 (Canada) \\ Department of Geological Sciences, University of Michigan, Ann Arbor, MI 48109 (U.S.A.)
}

(Received February 3, 1986; revised and accepted October 1, 1986)

\begin{abstract}
Cumming, G.L. and Kesler, S.E., 1987. Lead isotopic composition of the oldest volcanic rocks qf the eastern Greater Antilles island arc. Chem. Geol. (Isot. Geosci. Sect.), 65: 15-23.

$\mathrm{Pb}$ isotopic analyses for rocks from the early Cretaceous Los Ranchos Formation, which is the basal volcanic assemblage in the Dominican Republic, fall on a short linear array of shallow slope in a ${ }^{207} \mathrm{~Pb} /{ }^{204} \mathrm{~Pb} \mathrm{vs}{ }^{206} \mathrm{~Pb} /{ }^{204} \mathrm{~Pb}$ plot. The array is interpreted to have formed by decay of local $U$ since the time of ore and rock formation $\sim 110$ Ma ago. Previously reported analyses of sulfide samples from the Pueblo Viejo $\mathrm{Au}-\mathrm{Ag}$ deposit in the upper part of the Los Ranchos Formation fall on the lower half of the same linear array. In a ${ }^{208} \mathrm{~Pb} /{ }^{204} \mathrm{~Pb}$ vs. ${ }^{206} \mathrm{~Pb} /{ }^{204} \mathrm{~Pb}$ plot the Los Ranchos Format:on can be divided into the lower member with an apparent $\mathrm{Th} / \mathrm{U}$ ratio of 1.2 and the upper three members with an apparent $\mathrm{Th} / \mathrm{U}$ ratio of 2.6. A cluster of analyses falls at the least radiogenic end of these arrays and is interpreted to represent the initial $\mathrm{Pb}$ isotopic composition of the Los Ranchos magmas. This cluster falls close to the Stacey-Kramers growth curve. For the Los Ranchos $\mathrm{Pb}$, a homogeneous source with $\mu=9.6$ and $\mathrm{Th} / \mathrm{U}$ near 3.8 , since $3.7 \mathrm{Ga}$ ago, is implied.

Previously reported analyses for correlative rocks of the Water Island Formation, the basal volcanic complex in the Virgin Islands at the east end of the Greater Antilles, suggest a steep linear array extending downwards from the Los Ranchos cluster, after correction of the ratios for $U$ decay since formation of the rocks. This array has a slope of $0.250 \pm 0.023$, which could have resulted from magma derivation from sources that had been isolated for $\sim 3.0 \mathrm{Ga}$. Younger rock $\mathrm{Pb}$, from the island of Martinique, has a similar slope, although with larger ${ }^{206} \mathrm{~Pb} /{ }^{204} \mathrm{~Pb}$ and ${ }^{207} \mathrm{~Pb} /{ }^{204} \mathrm{~Pb}$ ratios. The data points extend upward from the radiogenic end of the Los Ranchos array.

'These relationships indicate a complex derivation of magmas in the area. In the Greater Antilles, the proportion of continental material decreases eastward, while even farther east in the Lesser Antilles at Martinique, the proportion of crustal material, as indicated by $\mathrm{Pb}$ isotopic composition, is again very high.
\end{abstract}

\section{Introduction}

The Los Ranchos Formation, which is located in the Dominican Republic (eastern Hispaniola, Fig. 1), is one of the oldest volcanic units in the central Greater Antilles island arc. It appears to correlate with the Water Island Formation in the Virgin Islands (Donnelly, 1966), which is comprised of generally similar lithologies and is also one of the oldest stratigraphic units exposed in the eastern Greater Antilles. $\mathrm{Pb}$ isotopic data for four rock samples from the Water Island Formation (Donnelly et al., 1971) are relatively low in radiogenic ${ }^{207} \mathrm{~Pb}$ in comparison to other rock and ore $\mathrm{Pb}$ from the Greater Antilles (Donnelly et al., 1971; Cum- 


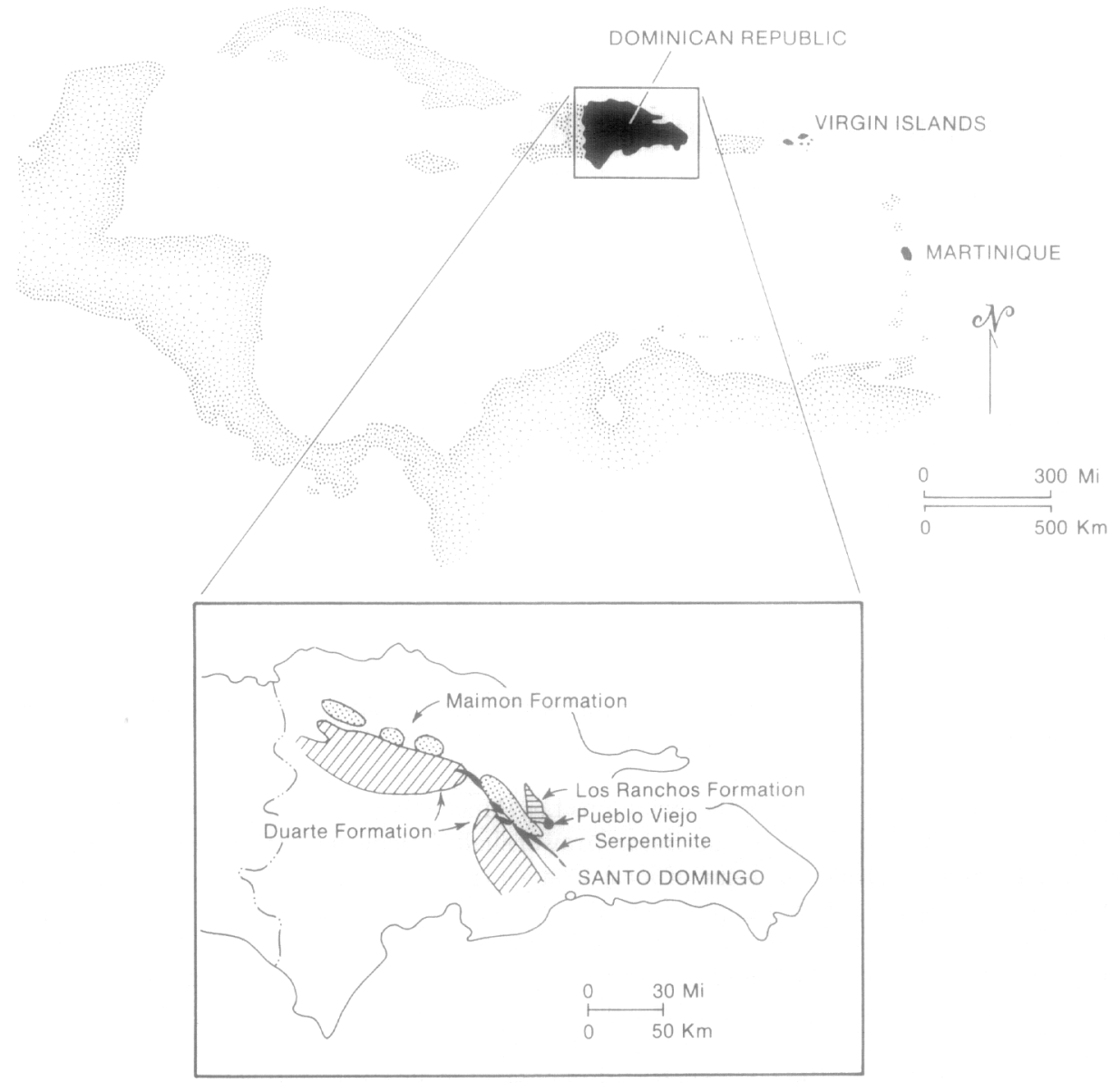

Fig. 1. Location of the Dominican Republic and Virgin Islands in the Greater Antilles. Martinique in the Lesser Antilles is also shown. The inset shows the regional geologic setting of the Los Ranchos Formation in relation to the pre-Albian Duarte metabasalt (sea floor?) and Maimon (-Amina) felsic to mafic metavolcanic rocks (island arc?).

ming et al., 1981). Ore Pb from the Pueblo Viejo $\mathrm{Au}-\mathrm{Ag}$ deposit, which is in the upper part of the Los Ranchos Formation, is also somewhat low in radiogenic ${ }^{207} \mathrm{~Pb}$ (Cumming and Kesler, 1976; Cumming et al., 1982) but form a short array of shallow slope. In this paper, we have attempted to evaluate the relationship between the Water Island and Los Ranchos Formations more fully by obtaining new $\mathrm{Pb}$ isotope data from rocks of the Los Ranchos Formation. Using these data along with those from the Water Island Formation and ore $\mathrm{Pb}$ from the Pueblo Viejo deposit (Cumming et al., 1982), we have assessed the early characteristics of sources for magmagenesis in the Greater Antilles.

\section{Geologic setting and characteristics of the Los Ranchos and Water Island Formations}

Both the Los Ranchos and Water Island Formations consist largely of a bimodal volcanic suite including basalt and dacite or rhyolite that have undergone extensive chemical interaction with seawater. The Water Island Formation contains abundant siliceous quartz keratophyre flows with smaller amounts of flow breccias and tuffs and spilite flows (Donnelly, 1966). All of these rocks have been altered by extensive interaction with seawater to assemblages containing chlorite, calcite, albite, epidote, pumpellyite and prehnite. The Water 
TABLE I

Lithology of major members of Los Ranchos Formation

\begin{tabular}{lc}
\hline $\begin{array}{l}\text { Pueblo Viejo } \\
\text { Member }\end{array}$ & $\begin{array}{c}\text { volcaniclastic, carbonaceous and pyri- } \\
\text { tic sediments with spilitic } \\
\text { flows(?) and keratophyre agglom- } \\
\text { erates in local basin or maar }\end{array}$ \\
$\begin{array}{l}\text { Platanal } \\
\text { Member }\end{array}$ & $\begin{array}{c}\text { spilitic flows and volcaniclastic sedi- } \\
\text { ments with lenses of fossiliferous } \\
\text { limestone, marl and shale }\end{array}$ \\
$\begin{array}{l}\text { Zambrana } \\
\text { Member }\end{array}$ & $\begin{array}{c}\text { volcaniclastic rocks with keratophyre } \\
\text { fragments }\end{array}$ \\
$\begin{array}{l}\text { Quita Sueño } \\
\text { Member }\end{array}$ & $\begin{array}{c}\text { keratophyre flows and stocks, some } \\
\text { fine-grained keratophyre tuffs and } \\
\text { local spilitic flows }\end{array}$ \\
\hline
\end{tabular}

Island Formation is overlain by the Louisenhoj Formation, which consists of augite-andesite breccias that have undergone somewhat less interaction with seawater. The absence of terrigenous sediment and explosive textures was cited by Donnelly (1966) as evidence that volcanic rocks of the Water Island Formation were emplaced at great water depths, whereas the fragmental Louisenhoj Formation was thought to have been emplaced in a shallow water or even a terrestrial environment.

The Los Ranchos Formation, which has been divided into four members (Table I), shows a generally similar stratigraphic distribution of fragmental units (Kesler et al., 1981). The lowermost member, the Quita Sueño, consists largely of keratophyre flows and stocks with some fine-grained keratophyre tuffs and local spilite flows. The overlying members of the Los Ranchos Formation (Table I) include tuffs and agglomerates that contain terrigenous sediments and are capped by a thick sequence of spilite flows and spilite volcaniclastic sediments. The uppermost unit in the Los Ranchos Formation, the Pueblo Viejo Member, hosts a large $\mathrm{Au}-\mathrm{Ag}$ deposit that formed contemporaneously with the host volcanic pile (Kesler et al., 1981). All of these rocks have been altered extensively by reaction with seawater to assemblages containing albite, epidote, calcite and chlorite. The abrupt increase in abundance of fragmental material above the Quita Sueño Member resembles that seen at the Water Island-Louisenhoj contact, suggesting that the upper Los Ranchos members actually correlate with the Louisenhoj Formation.

The age of the Water Island Formation is known from fossil evidence to be approximately Aptian-early Albian or $\sim 110-115 \mathrm{Ma}$ (Donnelly, 1966; T.W. Donnelly, pers. commun., 1984) . Whole-rock K/Ar ages of 58-62 \pm 5 $\mathrm{Ma}$ and 106-110 $\pm 10 \mathrm{Ma}$ reported for the Water Island Formation (Donnelly, 1966) probably in part represent reheating (Kesler et al., 1977). For the Los Ranchos Formation, the best age estimate is provided by terrestrial plant fossils found in the upper part of the formation, which suggest an early Cretaceous age (G.J. Smiley, pers. commun., 1978). Bowin (1966) reported an age of middle Aptian to middle Albian for marine fossils from one locality in the upper Los Ranchos Formation. As noted by Cumming et al. (1982), the $\mathrm{Pb}$ isotopic data for ore samples in the Pueblo Viejo deposit in the upper part of the Los Ranchos Formation support this age assignment. Younger ${ }^{39} \mathrm{Ar} /{ }^{40} \mathrm{Ar}$ ages of 61.6 and $67.8 \mathrm{Ma}$ for alunite in the Pueblo Viejo ore deposit (Kesler et al., 1981) are thought to reflect reheating. Thus, it appears that the Water Island and Los Ranchos Formations are indeed coeval and are the oldest units in the eastern Greater Antilles.

\section{Analytical methods}

Los Ranchos Formation rock samples were dissolved by refluxing overnight in Teflon ${ }^{\otimes}$ beakers using $10 \mathrm{ml}$ of concentrated $\mathrm{HF}$ and a little $\mathrm{HNO}_{3} . \mathrm{Pb}$ was separated in an anionexchange column using $\mathrm{HBr}-\mathrm{HCl}$. The same column in nitrate from was used to separate $U$. $\mathrm{Pb}$ blanks were 10-12 ng and the data have not been corrected for the blanks since the effect is negligible for these samples. 
TABLE II

$\mathrm{Pb} / \mathrm{U}$ concentrations

\begin{tabular}{llll}
\hline No. Sample I.D. & $\begin{array}{l}\mathrm{Pb} \\
(\mathrm{ppm})\end{array}$ & $\begin{array}{l}\mathrm{U} \\
(\mathrm{ppm})\end{array}$ & ${ }^{238} \mathrm{U} /{ }^{204} \mathrm{~Pb}$ \\
\hline
\end{tabular}

(a) Quita Sueño member:

$5 \quad 77$-104 (leached) $\quad 0.525 \quad 0.500 \quad 61.07$

$\begin{array}{lllll}6 & 73-604 & 1.316 & 0.323 & 15.77\end{array}$

(b) Upper Los Ranchos members:

\begin{tabular}{rrrrr}
11 & $73-617$ & 11.39 & 0.631 & 3.54 \\
14 & $73-511$ & 1.747 & 0.275 & 10.09 \\
\hline
\end{tabular}

All analyses were carried out on a Micromass ${ }^{\circledR}$ MM30 mass spectrometer. At the time these analyses, were carried out, measuring precision for $\mathrm{Pb}$ was as described in Cumming et al. (1982), that is, close to $0.04 \%$ per mass unit difference $(2 \sigma)$ as determined by 40 replicate analyses of N.B.S. SRM981. Data were normalized to near absolute values using the measured ratios of the standard.

\section{4. $\mathrm{U} / \mathrm{Pb}$ ratios}

Reconnaissance measurements of $\mathrm{Pb}$ and $\mathrm{U}$ concentrations were carried out on four samples and the data are shown in Table II. One sample (No. 5) was leached in $\mathrm{HCl}$ to test the relative solubilities of the $\mathrm{Pb}$ and $\mathrm{U}$ in the rocks. The $\mathrm{Pb}$ abundance is lower in the leached sample compared to the other samples, while little change is evident in the $\mathrm{U}$ concentration.

The U/Pb systems in the three other samples have clearly been disturbed since the original rock formation at $\sim 110 \mathrm{Ma}$ ago. In Fig. 2 we have indicated the position of an isochron beginning with an initial ${ }^{206} \mathrm{~Pb} /{ }^{204} \mathrm{~Pb}$ ratio of the average of the cluster of points in Fig. 3., as discussed below, with a slope corresponding to 110 Ma. The three sample points on the diagram are substantially depleted in $\mathrm{U}$, lying above the line, while the leached sample (No. 5) is well below the isochron line, indicating substantial differential $\mathrm{Pb}$ loss, presumably due to the leaching. It seems doubtful to us that a detailed

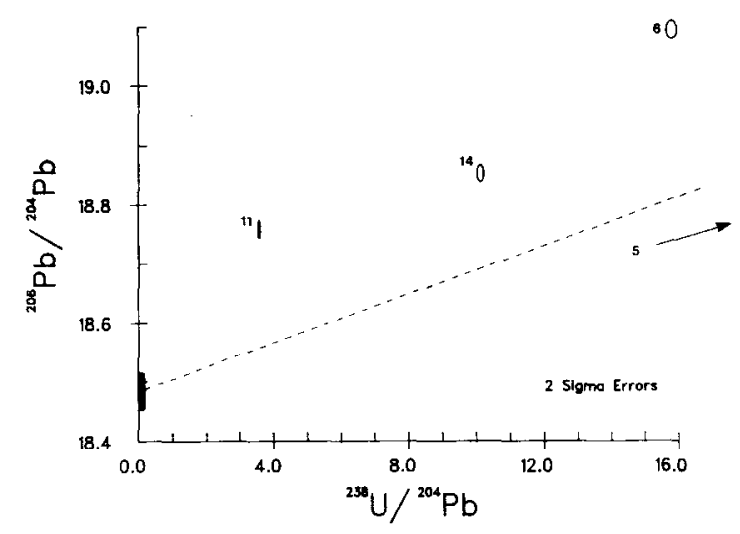

Fig. 2. U/Pb isochron diagram for rocks of the Los Ranchos Formation. Numbering as in Tables II and III. The dashed line indicates the expected position of a $110-\mathrm{Ma}$ isochron beginning at the estimated initial ${ }^{206} \mathrm{~Pb} /{ }^{204} \mathrm{~Pb}$ ratio indicated by the solid bar.

study of the U-Pb systematics can produce useful results, bearing in mind the altered nature of these rocks, and we have not pursued this problem any further.

\section{5. $\mathrm{Pb} / \mathrm{Pb}$ isotope ratios}

Table III contains the analytical results of our measurements of 17 rocks, as well as the 11 sulfides from the Pueblo Viejo deposit that were reported in Cumming et al. (1982). The data are plotted in Fig. 3 with different symbols for each class of material as indicated on the figure. Four additional analyses for the Water Island Formation (Donnelly et al., 1971) are also given in Table III and Fig. 3.

There are two data arrays on this plot that require explanation. The simplest of these is formed by the sulfides and rocks of the Los Ranchos Formation. Note that seven of the 11 sulfide samples from the Pueblo Viejo deposit as well as two samples of Pueblo Viejo member rocks form a tight cluster only slightly larger than the experimental error as indicated in Fig. 3. The remaining rock and sulfide data points fall along a linear array in the ${ }^{207} \mathrm{~Pb} /{ }^{204} \mathrm{~Pb}$ vs. ${ }^{206} \mathrm{~Pb} /{ }^{204} \mathrm{~Pb}$ plot, with an indication that rock $\mathrm{Pb}$ data, particularly from samples of the Quita Sueño member, tend to be somewhat more radi- 


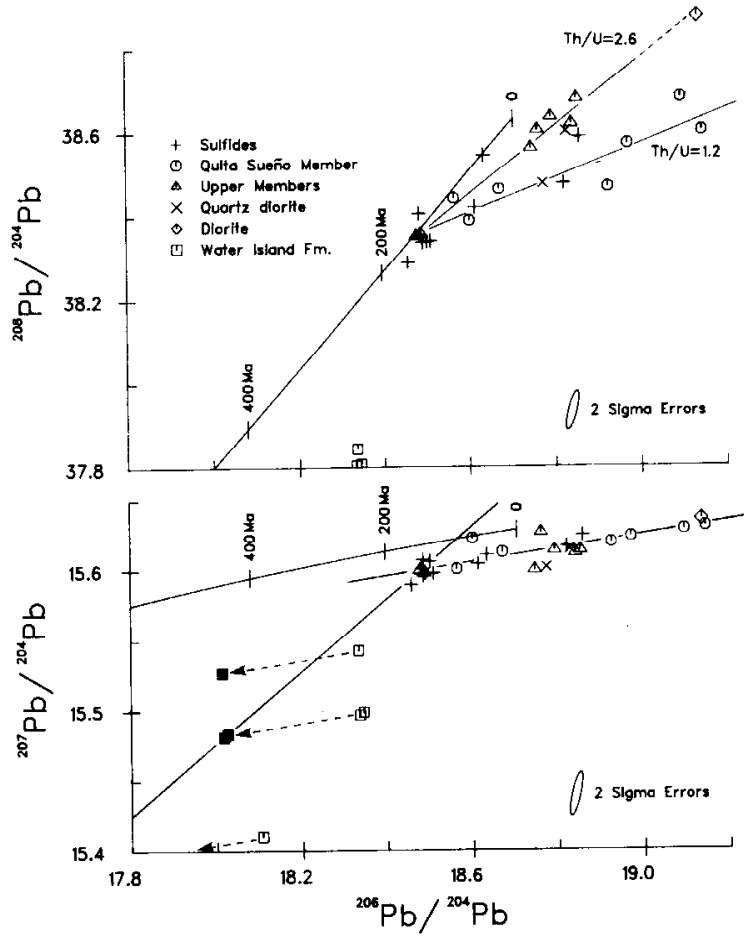

Fig. 3. $\mathrm{Pb} / \mathrm{Pb}$ diagram for Pueblo Viejo sulfide samples and rocks of the Los Ranchos Formation of the Dominican Republic. Rocks from the Water Island Formation of the Virgin Islands are shown as open squares (Donnelly et al., 1971). Solid squares are after corrections of the latter ratios for $110 \mathrm{Ma}$ of $\mathrm{Pb}$ evolution. One corrected value falls out of the field of the diagram. Two isochrons are discussed in the text. Error ellipse indicates the measuring error for the data presented here. The errors for the squares are $\sim 4$ times larger. The growth curves, shown for reference, are those of Stacey and Kramers (1975).

ogenic than the sulfides. On the plot of ${ }^{208} \mathrm{~Pb} /{ }^{204} \mathrm{~Pb}$ vs. ${ }^{206} \mathrm{~Pb} /{ }^{204} \mathrm{~Pb}$ in Fig. 3, the Quita Sueño member values are clearly on a line of shallow slope with some scatter, while the data for samples from the upper members closely define a line with distincly steeper slope. $\mathrm{Pb}$ isotope ratios from the sulfides in the Pueblo Viejo deposit are scattered on and between the two lines.

Since the ore deposit and the volcanic rocks are contemporaneous (Kesler et al., 1981), we can treat the rocks and sulfides as a single system. We therefore interpret these data as representing an initial $\mathrm{Pb}$ with a composition close to the cluster of data points, to which has been added radiogenic $\mathrm{Pb}$ from $\mathrm{U}$ and $\mathrm{Th}$ decay since the time of rock and ore formation. Some of the ore sulfides may have $U$ associated with them, which would provide the radiogenic additions and enable us to treat the ore sulfides in the same way as the rock $\mathrm{Pb}$. Thus the slope of the linear array of the ${ }^{207} \mathrm{~Pb} /{ }^{204} \mathrm{~Pb}$ vs. ${ }^{206} \mathrm{~Pb} /{ }^{204} \mathrm{~Pb}$ diagram may be used to determine the age of the ore and rocks from the usual isochron equation (Faure, 1977). This relation yields a line of slope $R=0.048 \pm 0.0065$ with mean squared weighted deviates of MSWD $=0.92$, as calculated by the method of Cumming et al. (1972). The age of the ore-rock system as determined from the slope of the regression line (on the assumption that the distribution of points is simply related to the time interval since formation) is $130 \mathrm{Ma}$, in good agreement with the fossil evidence as discussed above. Such agreement must, however, be considered as fortuitous, since the slope age is not closely defined due to the short line and the magnitude of the experimental errors.

Confirmation for the essential validity of the slope age is provided by the composition of the cluster of points for the ore $\mathrm{Pb}$. The cluster lies just below the Stacey and Kramers (1975) growth curve for which they determined a second-stage $\mathrm{U} / \mathrm{Pb}$ ratio of $\mu=9.74$. Changing this value to 9.66 generates a growth curve that passes through the ore $\mathrm{Pb}$ cluster at an age of $110 \mathrm{Ma}$, in excellent agreement with the fossil indications and the slope age. Using this age, we have calculated $\mathrm{Th} / \mathrm{U}$ ratios from the slopes of the ${ }^{208} \mathrm{~Pb} /{ }^{204} \mathrm{~Pb}$ vs. ${ }^{206} \mathrm{~Pb} /{ }^{204} \mathrm{~Pb}$ arrays in Fig. 3. The slope of the line for the Quita Sueño data indicates an average $\mathrm{Th} / \mathrm{U}$ ratio of only 1.2 $(M S W D=6.4)$, lower than the line through the data for the upper members, which yields a $\mathrm{Th} / \mathrm{U}$ ratio of $2.6(\mathrm{MSWD}=1.7)$. It is important to note that the two lines intersect close to the Stacey and Kramers (1975) growth curve, indicating that the $\mathrm{Th} / \mathrm{U}$ ratio in the source of all units of the Los Ranchos Formation was nearly that of the "average earth" (3.8), while the $\mathrm{Th} / \mathrm{U}$ ratio in the rocks after their forma- 


\section{TABLE III}

$\mathrm{Pb}$ isotope ratios - Los Ranchos Formation and related rocks and minerals

\begin{tabular}{|c|c|c|c|c|}
\hline No. & Sample i.d. & ${ }^{206} \mathrm{~Pb} /{ }^{204} \mathrm{~Pb}$ & ${ }^{207} \mathrm{~Pb} /{ }^{204} \mathrm{~Pb}$ & ${ }^{208} \mathrm{~Pb} /{ }^{204} \mathrm{~Pb}$ \\
\hline \multicolumn{5}{|c|}{ (a) Quita Sueño member (lower Los Ranchos): } \\
\hline 1 & $72-71$ & 18.565 & 15.601 & 38.442 \\
\hline 2 & $78-30-\mathrm{B}(\mathrm{H})$ & 18.602 & 15.623 & 38.389 \\
\hline 3 & $78-1$ & 18.671 & 15.613 & 38.463 \\
\hline 4 & $78-24$ & 18.925 & 15.620 & 38.468 \\
\hline 5 & $77-104$ & 18.971 & 15.624 & 38.572 \\
\hline 6 & 73-604 & 19.095 & 15.629 & 38.681 \\
\hline 7 & $78-15$ & 19.145 & 15.631 & 38.602 \\
\hline \multicolumn{5}{|c|}{ (b) Upper Los Ranchos members: } \\
\hline 8 & DDH86A-11M & 18.477 & 15.600 & 38.353 \\
\hline 9 & 165-91M-RC(PQK) & 18.488 & 15.598 & 38.357 \\
\hline 10 & $73-383$ & 18.745 & 15.600 & 38.561 \\
\hline 11 & $73-617(\mathrm{H})$ & 18.760 & 15.627 & 38.604 \\
\hline 12 & $73-538$ & 18.792 & 15.614 & 38.635 \\
\hline 13 & $77-37$ & 18.841 & 15.612 & 38.619 \\
\hline 14 & $73-511$ & 18.853 & 15.614 & 38.678 \\
\hline \multicolumn{5}{|c|}{ (c) Intrusives: } \\
\hline 15 & 73-599 quartzdiorite & 18.773 & 15.602 & 38.476 \\
\hline 16 & 78-17 quartzdiorite & 18.828 & 15.615 & 38.601 \\
\hline 17 & 72-82 Diorite & 19.136 & 15.636 & 38.873 \\
\hline \multicolumn{5}{|c|}{ (d) Water Island Formation: } \\
\hline 18 & $68-1-20$ & 18.336 & 15.497 & 37.844 \\
\hline 19 & $61-80 \mathrm{C}$ & 18.106 & 15.410 & 37.461 \\
\hline 20 & $63-76 \mathrm{~A}$ & 18.345 & 15.499 & 37.807 \\
\hline 21 & 425 & 18.333 & 15.543 & 37.804 \\
\hline \multicolumn{5}{|c|}{ (e) Pueblo Viejo sulfide samples: } \\
\hline $22^{*}$ & DDH162-171-G-V & 18.457 & 15.590 & 38.290 \\
\hline $23^{*}$ & DDH100-16-Py-L & 18.482 & 15.601 & 38.406 \\
\hline $24^{*}$ & T-6-2-Py-V & 18.485 & 15.608 & 38.356 \\
\hline $25^{*}$ & DDH71-107-Py-L & 18.486 & 15.597 & 38.355 \\
\hline $26^{*}$ & T-2-5-Py-L & 18.490 & 15.599 & 38.338 \\
\hline $27^{*}$ & DDH92-46-G-V & 18.500 & 15.607 & 38.340 \\
\hline $28^{*}$ & DDH174-56M-Py-V & 18.509 & 15.598 & 38.341 \\
\hline $29^{*}$ & DDH162-83M-Py-L & 18.615 & 15.605 & 38.421 \\
\hline 30 & DDH101-21M-Py-L & 18.635 & 15.611 & 38.544 \\
\hline 31 & DDH163-83M-En-V & 18.821 & 15.617 & 38.477 \\
\hline $32^{*}$ & DDH161-123M-En.V & 18.859 & 15.625 & 38.589 \\
\hline
\end{tabular}

$(a),(b)$ and (c): New analyses; (d): Donnelly et al. (1971); (e): Cumming et al. (1981).

${ }^{*}$ Average of two analyses.

tion was very significantly reduced. This may be due to some complex history of interaction with seawater or to some geochemical process associated with the differentiation of the rocks from their ultimate source.
Table III contains data on three samples of intrusive rocks. The quartz diorite is believed to be comagmatic with the extrusive rocks. On the other hand, there is evidence that the diorite is considerably younger (Bowin, 1966). The 
samples have $\mathrm{Pb}$ isotopic compositions which are very similar to the volcanic units, indicating closely related sources for the intrusive and extrusive rocks.

Analysis of the steeper array suggested by the Los Ranchos Formation cluster and the compositions for the Water Island Formation is facilitated by correcting the latter data to their original, early Cretaceous compositions. $\mathrm{U} / \mathrm{Pb}$ ratios necessary to do this are not available so we have estimated an average value of 16 , based on the distribution of points on the linear array formed by the $\mathrm{Pb} / \mathrm{Pb}$ data from the Los Ranchos Formation (Fig. 3). The measured U/Pb ratios were not considered to be a large enough population to obtain a valid average. The fact that the corrected ratios do not fall precisely on a single array after this correction may be a reflection of the variation in the actual $U / P b$ ratios of these samples. Notwithstanding this problem, the use of any reasonable $\mathrm{U} / \mathrm{Pb}$ ratio would yield a steep array extending upwards from Water Island compositions to the Los Ranchos cluster, and it is this array that requires explanation.

This Los Ranchos-Water Island array indicates a substantial variation in initial ${ }^{207} \mathrm{~Pb} /{ }^{204} \mathrm{~Pb}$ ratios for the Water Island and Los Ranchos magmas, which could reflect either a corresponding heterogeneity in the mantle source region for the magmas or mixing between mantle $\mathrm{Pb}$ and some other $\mathrm{Pb}$ during magmagenesis. Davidson (1983) has observed a similar steep array (line 5, Fig. 4 ) for volcanic rocks of Martinique in the Lesser Antilles and suggested that it represents a mixing line between mantle and terrigenous sediment. Whereas some information is available on the isotopic composition of sediments that might have been involved in magmagenesis in the Lesser Antilles (Thirlwall and Graham, 1984), no such information is available for early Cretaceous and older sediments that might have been consumed during the Greater Antilles magmagenesis.

We note that the upper limit of the Los Ran-

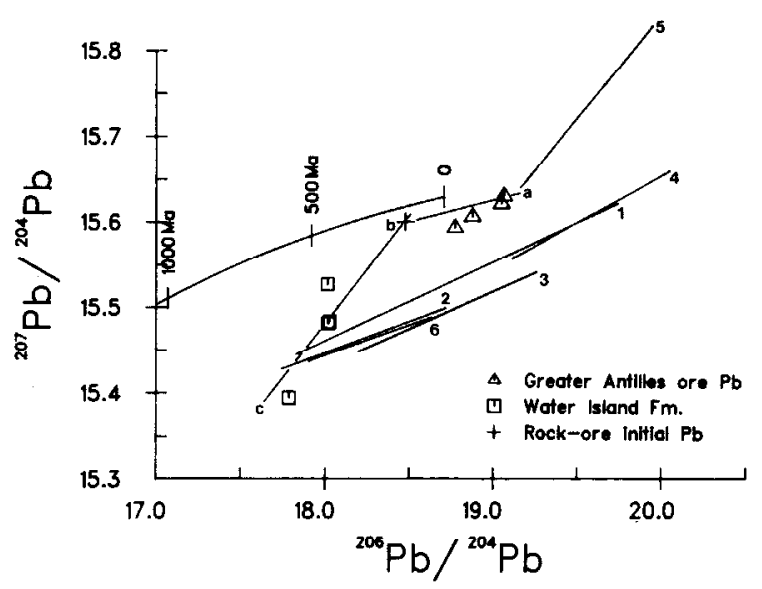

Fig. 4. Relationship of Pueblo Viejo linear array $(a-b)$ to other oceanic arrays. $1=$ North Atlantic (Dupré and Allègre, 1980);2=Mid-Atlantic (Tatsumoto, 1978);3=Iceland and Reykjanes Ridge, (Sun and Jahn, 1975; Sun et al., 1975); $4=$ Canary Islands (Sun, 1980); $5=$ Martinique (Davidson, 1983); $6=$ Hawaii (Tatsumoto, 1978); $b-c=$ Water Island Formation (Donnelly et al., 1971). Greater Antilles ore $\mathrm{Pb}$ from Cumming et al. (1981) are shown as triangles. Growth curve as in Fig. 3.

chos-Water Island array, as defined by the Los Ranchos cluster, is generally similar to the composition of pelagic sediments (Doe and Zartman, 1979; Zartman and Doe, 1981). It does not extend to compositions typical of cratons or craton-derived sediment which would be substantially above the growth curve shown. This is in agreement with the fact that the eastern Greater Antilles does not include continental fragments and was not adjacent to a craton in early Cretaceous time (Pindell and Dewey, 1982). The fact that the Water Island rocks exhibit a greater heterogeneity and a less radiogenic character than the Los Ranchos Formation, with the least radiogenic Water Island samples showing compositional similarity to MORB (lines 1-3, Fig. 4), suggests that the degree of mixing would have been greatest for the Los Ranchos magmas.

,If the steep Los Ranchos-Water Island array were generated by long-lived heterogeneities in the mantle, then the slope of the array $(R=0.251 \pm 0.022)$ with $\mathrm{MSWD}=1.05$ and $t_{2}=110 \mathrm{Ma}$ indicates $\mathrm{a} t_{1}$ of $3200 \pm 300 \mathrm{Ma}(2 \sigma)$ 
for the two-stage model of Gale and Mussett (1973). This calculation depends greatly on the $\mathrm{U} / \mathrm{Pb}$ ratios assigned above and would range between 2500 and $4200 \mathrm{Ma}$ for $\mathrm{U} / \mathrm{Pb}$ ratios of $\mu=32$ and $\mu=0$, respectively. These ages suggest the possibility that the first major separation of crustal material form the mantle from which the Water Island and Los Ranchos magmas were derived, may have occurred very early in the history of the region.

The relation between the isotopic composition of the Los Ranchos-Water Island magmas and later volcanic rocks in the Greater Antilles can be estimated from the limited data available on ore deposits in these younger rocks (Cumming and Kesler, 1976; Cumming et al., 1982). Present information on the origin of these deposits indicates that the metals in the deposits were scavenged from the surrounding volcanic and volcaniclastic rocks by circulating hydrothermal solutions that were active at approximately the time of formation of the volcanic rocks (Kesler, 1978). Accordingly, the isotopic composition of the ores should reflect the isotopic composition of their host volcanic pile. Note that the $\mathrm{Pb}$ in late Cretaceous ore deposits from Haiti and Puerto Rico, as well as from an Eocene deposit in Jamaica, fall generally along the shallow array of the Los Ranchos Formation (Fig. 4). It is clear that these younger Greater Antilles volcanic rocks were derived from a source that was more similar to the Los Ranchos Formation than to the Water Island Formation and that, at least in terms of $\mathrm{Pb}$ isotopic characteristics, there was not a major change in magmagenesis between Water Island-Los Ranchos time and later volcanism in the Greater Antilles, as has been suggested on the basis of major and minor element data (Donnelly and Rogers, 1978). Rather, it appears that there was significant variation in magmagenesis during the early stages of evolution of the Greater Antilles and, at least as far as can be determined from the limited data, less variation later.

\section{Conclusions}

The distribution of $\mathrm{Pb}$ isotope ratios from the Los Ranchos Formation is consistent with the Cretaceous age for the rocks, both from the slope of the $\mathrm{Pb} / \mathrm{Pb}$ isochron and from the initial $\mathrm{Pb}$ isotopic compositions. The ore $\mathrm{Pb}$ is very similar in composition to the host rocks, supporting the view that the ore was derived from the surrounding rocks. The initial $\mathrm{Pb}$ composition indicates a source with $\mu=9.66$, and a $\mathrm{Th} / \mathrm{U}$ ratio close to 3.8 . The isotope ratios are thus similar to those predicted by the Zartman and Doe (1981) plumbo-tectonic model for the average orogene. The data indicate a substantial reduction of the $\mathrm{Th} / \mathrm{U}$ ratio for the rocks, and this must have occurred close to the time of formation since the ore $\mathrm{Pb}$ also shows the same reduced values.

On a broader scale, the isotopic data suggest a substantial well-homogenized crustal component in the Cretaceous rocks of Hispaniola while the data from the Virgin Islands, further from the continent, are more variable and generally much lower in ${ }^{207} \mathrm{~Pb}$, indicating a larger mantle component in the rocks. Still further east in the Lesser Antilles at Martinique, ${ }^{207} \mathrm{~Pb}$ is again elevated and variable, indicating a greatly increased crustal component, presumably derived from terriginous sediments subducted during the development of the Lesser Antilles arc.

\section{Acknowledgements}

This work was supported in part by grant A1166 from the Natural Sciences and Engineering Research Council of Canada to G.L.C. and by grant EAR77-13675 from the United States National Science Foundation to S.E.K. Isotopic analyses were carried out at theUniversity of Alberta by D. Krstic. We are grateful to M. Seaward, N. Russell, K. McCurdy, J.F. Lewis and T.W. Donnelly for discussion of 
aspects of the geology and geochemistry of the Los Ranchos and Water Island Formations.

\section{References}

Bowin, C.O., 1966. Geology of the central Dominican Republic. Geol. Soc. Am., Mem. No. 98, pp. 11-84.

Cumming, G.L. and Kesler, S.E., 1976. Source of lead in Central America and Caribbean mineralization. Earth Planet. Sci. Lett., 31: 262-268.

Cumming, G.L., Rollett, J.S,, Rossotti, F.J.C. and Whewell, R.J., 1972. Statistical methods for the computation of stability constants, Part I. Straight-line fitting of points with correlated errors. J. Chem. Soc. London, Dalton Trans., Inorg. Chem., pp. 2652-2658.

Cumming, G.L., Kesler, S.E. and Krstic, D., 1981. Source of lead in Central America and Caribbean mineralization, II. Lead isotope provinces. Earth Planet. Sci. Lett., 56: 199-209.

Cumming, G.L., Kesler, S.E. and Krstic, D., 1982. Source of lead in sulfide ore at the Pueblo Viejo gold-silver oxide deposit, Dominican Republic. Econ. Geol., 77: 1939-1942.

Davidson, J.P., 1983. Lesser Antilles isotopic evidence of the role of subducted sediment in island arc magma genesis. Nature (London), 306: 253-256.

Doe, B.R. and Zartman, R.E., 1979. Plumbotectonics, the Phanerozoic. In: H.L. Barnes (Editor), Geochemistry of hydrothermal ore deposits, Wiley-Interscience, New York, N.Y., pp. 22-70.

Donnelly, T.W., 1966. Geology of St. Thomas and St. John, U.S. Virgin Islands. Geol. Soc. Am., Mem. No. 98, pp. 85-176.

Donnelly, T.W. and Rogers, J.J.W., 1978. Igneous series in island arcs: The northeastern Caribbean compared with world-wide island-arc assemblages. Bull. Volcanol., 43: 347-382.

Donnelly, T.W., Rogers, J.J.W., Pushkar, P. and Armstrong, R.L., 1971. Chemical evolution of the igneous rocks of the eastern West Indies: an investigation of thorium, uranium, and potassium distributions, and lead and strontium isotopic ratios. Geol. Soc. Am., Mem. No. 130, pp. 181-224.

Dupré, B. and Allègre, C.J., 1980. Pb-Sr-Nd isotopic cor- relation and the chemistry of the North Atlantic mantle. Nature (London), 286: 17-22.

Faure, G., 1977. Principles of Isotope Geology. Wiley, New York, N.Y., 464 pp.

Gale, N.H. and Mussett, A.E., 1973. Episodic uranium-lead models and the interpretation of variations in the isotopic composition of lead in rocks. Rev. Geophys. Space Phys., 11: 37-86.

Kesler, S.E., 1978. Metallogenesis of the Caribbean region. J. Geol. Soc. London, 135: 429-441.

Kesler, S.E., Lewis, J.F., Jones, L.M. and Walker, R.L., 1977. Early island-arc intrusive activity, Cordillera Central, Dominican Republic. Contrib. Mineral. Petrol, 65: 91-99.

Kesler, S.E., Russell, N., Seaward, M., Rivera, J., McCurdy, K., Cumming, G.L. and Sutter, J.F., 1981. Geology and geochemistry of sulfide mineralization underlying the Pueblo Viejo gold-silver oxide deposit, Dominican Republic. Econ. Geol., 76: 1096-1117.

Pindell, J. and Dewey, J.F., 1982. Permo-triassic reconstruction of western Pangea and the evolution of the Gulf of Mexico/Caribbean region. Tectonics, 1: 179-211.

Stacey, J.S. and Kramers, J.D., 1975. Approximation of terrestrial lead isotope evolution by a two-stage model. Earth Planet. Sci. Lett., 26: 207-221.

Sun, S.-S., 1980. Lead isotopic study of young volcanic rocks from mid-ocean ridges, ocean islands and island arcs. In: The Evidence for Chemical Heterogeneity in the Earth's Mantle. Philos. Trans. R. Soc. London, Ser. A, 297: 409-445.

Sun, S.-S. and Jahn, B.M., 1975. Lead and strontium isotopes in post-glacial basalts from Iceland. Nature (London ), 255: 527-530.

Sun, S.-S., Tatsumoto, M. and Schilling, J.-G., 1975. Mantle plume mixing along the Reykjanes Ridge axis: lead isotopic evidence. Nature (London), 190: 143-147.

Tatsumoto, M., 1978. Isotopic composition of lead in oceanic basalts and its implication to mantle evolution. Earth Planet. Sci. Lett., 38: 63-87.

Thirlwall, M.F. and Graham, A.M., 1984. Evolution of high$\mathrm{Ca}$, high-Sr $\mathrm{C}$ series basalts from Granada, Lesser Antilles: The effects of intracrustal contamination. J. Geol. Soc. London, 141: 427-445.

Zartman, R.E. and Doe, B.R., 1981. Plumbotectonics The model. Tectonophysics, 75: 135-162. 